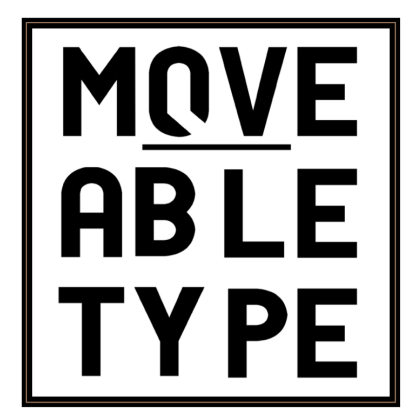

Writing Adolescence: Coming of Age in and Through What Maisie Knew, Lolita, and Wide Sargasso Sea

Author[s]: Amy Lankester-Owen

Source: MoveableType, Vol.1, 'Childhood and Adolescence' (2005)

DOI: $10.14324 / 111.1755-4527.003$

MoveableType is a Graduate, Peer-Reviewed Journal based in the Department of English at UCL.

(C) 2005 Amy Lankester-Owen. This is an Open Access article distributed under the terms of the Creative Commons Attribution License (CC-BY) 4.0https://creativecommons.org/licenses/by/4.0/, which permits unrestricted use, distribution, and reproduction in any medium, provided the original author and source are credited.

\title{
UCLPRESS
}




\section{Writing Adolescence: Coming of Age in and Through What Maisie Knew, Lolita, and Wide Sargasso Sea Amy Lankester-Owen}

\section{Introduction}

Adolescence, the transition from childhood to adulthood, is a turbulent time of rapid physical growth and sexual development. It also constitutes a critical phase in the formation of identity and vocation. In what follows I shall explore the ways in which representations of adolescence in three literary novels - Henry James's What Maisie Knew (1897), Vladimir Nabokov's Lolita (1955), and Jean Rhys's Wide Sargasso Sea (1966) - both reflect and shape their authors' writing lives. My analysis is supported throughout by psychological theories of adolescence, and draws in particular on the psychosocial developmental theory of Erik H. Erikson.

In their autobiographies Henry James, Vladimir Nabokov, and Jean Rhys each participate in different ways in the literary tradition of 'auto/biographical' writing identified by Laura Marcus.[1]All three authors stress the importance of adolescence as a defining and critical period in their own writing lives. Their fictionalized accounts are marked by a concern with identity and the potential for self-definition in adolescence. While James's Maisie seems to represent the essence of childhood potential realizable in adolescence, the adolescent potential of Nabokov's Lolita is thwarted cruelly by Humbert Humbert's appropriation of her childhood. Rhys paradoxically enables her character Antoinette to attain a kind of self-definition through her re-description of Antoinette's suicide.

I conclude by placing these three works of fiction in the context of their authors' writing careers. I argue that in each case the novels of female adolescence play a particular developmental role within the career trajectories of their authors. All three authors experienced a marked phase of transition followed by a re-definition of their identity as writer. They experience a recurrence of adolescence as they move into a new phase of their writing.

\section{Adolescence and Erikson's Psychosocial Model of Development}

The adolescent transition is often conceived of as a turbulent, rebellious period of hormonal flux, fluctuating moods, and sexual exploration. The work of Anna Freud, which explored in greater detail her father Sigmund Freud's conception of adolescence as a period when the powerful resurgent drives of the id create conflict and ego-identity confusion, has contributed considerably to this contemporary notion.[2] Yet adolescence in particular is the time when an individual's sense of identity and vocation is formed.

The psychologist Erik H. Erikson responded to the psychoanalytic ideas of both Sigmund and Anna Freud. Building on the Freuds' work on childhood development, 
he devised a specifically 'psychosocial' rather than psychosexual developmental theory. Emphasizing the social aspects of personality formation, Erikson stated specifically that he felt psychoanalysis as a whole had paid too little attention to the question of societal and community realms.[3] Erikson's theories complement and contextualize Sigmund Freud's five-phase model of childhood psychosexual maturation.[4] It is significant that Erikson's model of lifespan development adds three adult phases of development to Freud's five. These relate to tasks such as forming intimate relationships and being a parent, achieving satisfaction and 'generativity' through work, and preparing for the end of life.[5]

'Adolescence' is defined by the fifth edition of The Shorter Oxford Dictionary as 'the process or condition of growing from childhood to manhood or womanhood; the period of growing up'.[6] Erikson's inclusion of three adult phases in his model of development supports a commonsense definition of the adolescent phase as a critical period of transition, a bridging of childhood and adulthood. Erikson describes adolescence and the search for identity as the most important stage of development, and devotes much of his writing and research to this specific developmental 'crisis'. The central developmental task of adolescence, the major preparation for adulthood, is the formation of ego-identity, drawing on childhood and current experiences and identifications.[7] Adolescence is thus central to the individual's sense of self and direction. According to Erikson, 'an optimal sense of identity [...] is experienced merely as a sense of psychosocial well-being. Its most obvious concomitants are a feeling of being at home in one's body, a sense of "knowing where one is going," and an inner assuredness of anticipated recognition from those who count'.[8]

\section{Adolescence and Identity in the Authors' Autobiographies}

In their autobiographies James, Nabokov, and Rhys each describe transitional, defining experiences during adolescence. It is when these authors are adolescents that they realise the significance of writing to them, and begin to feel a sense of their identity as writers. The volumes which have become known as James's 'autobiography' concentrate on his development of vocation and a unitary sense of his writing identity. Nabokov's autobiography Speak, Memory (1967) playfully interweaves the narration of his adolescent sexual development with that of his coming of age as a writer. In Smile Please: An Unfinished Autobiography (1979), Rhys reflects a different sort of portrayal of the adolescent self-as-writer: she represents writing as a process constitutive of self.

\section{Henry James's Autobiography}

The first volume of what has become known as James's 'autobiography', entitled $A$ Small Boy and Others, relates to the author's childhood and early adolescence; it was begun when he was sixty-eight and was published in 1913. As Frederick Dupee points out in the introduction to his edition of the autobiography, James was then a contemporary of the much younger Joyce and Proust.[9] 
For the adolescent James, transitional, identity-forming moments occur when he is in Europe for the first time, aged fifteen. Europe signified Culture and Art for James, as it did for his family, whom Dupee describes as 'pioneers in the American rediscovery of Europe' in the mid-nineteenth century.[10] James recalls an almost visionary realization as he stood on a balcony overlooking the Rue de la Paix in Paris of 'this mystery, one's property - that of one's mind'.[11] In England, a few days prior to this balcony scene, James's adolescent perceptions are characterized in charged and positive terms. He recollects 'the London room about me, the very smell of which was ancient, strange and impressive, a new revelation altogether, and the window open to the English June and the far off hum of a thousand possibilities'.[12]

James's language here recalls the literary tradition of the epiphanic birth of the artist. His experiences can also be read in terms of the Eriksonian model of adolescence as the developmental stage characterized by the formation of identity. Erikson describes the apprehension of one's sense of identity 'as a recognition, almost as a surprise [...] a challenge "without guarantee"'.[13] James's use of the word 'revelation', and his 'hum' of 'possibilities', suggest that he was experiencing a comparable apprehension of self.

James's description of adolescence does not refer to his sexual coming of age. Hugh Stevens has argued that an unnamed sexual undercurrent seems to run through the volumes of James's autobiography. [14] Stevens reads the visionary dream in which James recalls a visit to the Galerie d'Apollon in the Louvre (Autobiography, pp. 196-97) as an instance of 'homospectrality'. In Stevens's persuasive argument, the dream, which brings up themes of haunting, masculinity, and an anxious doubling of self, signifies the merging of art with the erotic. James's autobiography arguably develops out of the predominantly masculine tradition of autobiographical writing identified by Laura Marcus as a predominantly Western, Christian 'canon' of introspective writing traceable through Wordsworth back to Rousseau, and to the confessional writing of St Augustine.[15] James is thus able to sidestep the issue of his sexual self precisely because he is writing about the formation of his identity as writer.

\section{Vladimir Nabokov's Speak, Memory}

Speak, Memory, published in 1967, is a revised edition of a work originally published as Conclusive Evidence in 1947, and begun when Nabokov was 37.[16] If James's late autobiography can be viewed as a Modernist work, Nabokov's is postmodern, playfully interrogating the boundaries between biographical fact and fiction, and ironizing the medium of autobiography. Unlike James's, Nabokov's narrative of the development of his younger, adolescent self in Speak, Memory is patterned as a dual evolution along both 'psychosocial' and 'psychosexual' trajectories. 
Nabokov suggests early in the work that 'the following of [...] thematic designs through one's life should be [...] the true purpose of autobiography'. He later elaborates, 'I confess I do not believe in time. I like to fold my magic carpet, after use, in such a way as to superimpose one part of the pattern upon another'. [17] Nabokov uses this characteristic patterning of themes to complicate and enrich his portrayal of his adolescent transition.

The vision of a raindrop which inspired the wonder and sense of revelation which led Nabokov to write his first poem is described in what seems to be richly sexual imagery: the raindrop's liquid 'globule of quicksilver' rolls down a leaf, '[performing] a sudden glissando down the center vein', then, 'having shed its bright load, the relieved leaf unbent'.[18] The author recounts in the same chapter how, in his teens, he asked his parents about his first experiences of sexual arousal, not understanding what was happening to him. His father provided a brief explanation using an analogy about blushes. The reader then learns, almost immediately, as the young author himself did, the seemingly unrelated fact that 'Tolstoy vient de mourir': 'Tolstoy has just died'.[19] Given Nabokov's love of coincidence, we can reasonably take the implication to be, at least in part, that a father of Russian literature has died on the same day that a young Russian writer-to-be has reached sexual awakening, the beginning of the search for his own status and vocation.

Nabokov's adolescent identity thus begins to take shape in relation to other writers. Erikson's pragmatic view of adolescence does not set the writer apart from other individuals. While Freud and Freudian theories concentrate on the development of the sexual drives,[20] Erikson focuses on the social, non-individualized aspects of development. Erikson's theory posits that identity formation in adolescence takes place in relation to 'society', whether that means 'some wider section of the neighbourhood block, an anticipated occupational field, an association of kindred minds, or perhaps [...] the "mighty dead"'.[21] In patterning a parallel evolution of his sexual and literary development, Nabokov participates in and at the same time ironizes the literary-autobiographical tradition exemplified by James's work. While Nabokov's suggestion is of a duality, a multiplicity, of identity, James's autobiography focuses on the purity and unity of the writer's identity.

\section{Jean Rhys's Smile Please: An Unfinished Autobiography}

Rhys's 'unfinished autobiography' Smile Please, produced in collaboration with David Plante, was begun when she was 86 and published posthumously in 1979.[22] In Rhys's account, the experience of writing began for her during late adolescence when she was living alone in Chelsea, recovering from the end of a relationship and an illegal abortion.[23] Rhys relates how she found herself writing continuously, as if under compulsion, reporting that 'I filled three exercise books and half another, then I wrote "Oh, God, I'm only twenty and I'll have to go on living and living and living". I knew then that it was finished and that there was no more to say'.[24] Thus, for Rhys, at this point in her life, writing is a process and a survival 
mechanism, even a component of self. Diana Athill, Rhys's editor at André Deutsch, suggested that writing was 'at least partly therapeutic' for Rhys.[25]

When Rhys comes to frame her identity as a writer, in a manner comparable to the revelatory experiences in adolescence narrated by James and Nabokov, it is in an extract from her diary published as an appendix in the autobiography.[26]

The appendix containing parts of Rhys's diary was, according to Athill, written in the 1940s when Rhys was in middle adulthood and her four early novels were out of print.[27] In it she defines herself in relation to other writers.[28] She asserts: 'I must write. If I stop writing my life will have been an abject failure [...] to myself. I will not have earned death'.[29] In her middle age, Rhys demonstrates a strong commitment to being a professional writer, despite the fact that her books are no longer in print. I would like to suggest that Rhys is experiencing a kind of recurrence of the identity crisis of adolescence. Like James and Nabokov, she expresses her sense of being a writer.[30]

Erikson suggests that one's sense of identity continues to develop throughout the life cycle, stating that while adolescence 'is the stage of an overt identity crisis, identity formation neither begins nor ends with adolescence: it is a lifelong development'.[31] In 'From a Diary' Rhys briefly recollects her actual adolescence, when she first travelled to England from Dominica. It seems that the period in which the diary was written coincided with another significant shift in identity for the author.[32]

\section{The Novels of Adolescence}

The three novels I shall now discuss represent their characters' adolescences in ways that reflect the central importance to their authors of identity and vocation. James's Maisie is emblematic of childhood potential and the adolescent transition into a fuller sense of identity, and is arguably an autobiographical portrait of James himself. Lolita's adolescent development is thwarted along both the trajectories - the psychosocial and psychosexual - in which Nabokov's autobiography revels. Rhys recasts her character Antoinette's suicide, which will take place within the pages of Brontë's Jane Eyre, as a form of self-definition - a violent reclamation of identity.

\section{Maisie in What Maisie Knew: Unlimited Potential}

In the introduction to his edition of What Maisie Knew, Paul Theroux suggests that 'in describing the slam-bang of her upbringing [James] has given us every reason for [Maisie's] turning out crazy, vengeful or anti-social'.[33] Nevertheless, in his Preface (1908) to the New York edition of the novel James describes how Maisie is able to transform the vulgarity and emptiness of her surroundings and the behaviour of the adults around her into 'the stuff of poetry and tragedy and art'.[34] It is Maisie's 
aesthetic sensibility, above all - her capacity to observe and imagine - that ensures that the 'child's identity is guarded and preserved'.[35]

Leon Edel argues that Maisie is a directly autobiographical portrait of the young James as portrayed in A Small Boy and Others, though oddly he makes no mention of their disparity of gender.[36] Yet Edel reads Maisie as a young child throughout the book (she is five at the beginning of the novel) and interprets the novel as spanning just two or three years in Maisie's development.[37] I would suggest, with a minority of critics, including Paul Theroux, that Maisie in fact reaches early adolescence in the novel. Theroux's reading of Maisie's age is based on his observation that Maisie experiences desire and increased physical maturity in the novel.[38] An autobiographical reading of the character Maisie in terms of James's own development of his sense of identity as artist during his adolescence lends further weight to the interpretation that Maisie grows into early adolescence in the course of the novel.

Towards the end of the novel when Maisie is in Boulogne James begins to portray his character's perceptions in a different way as she observes the beach and bathers in the late afternoon. We read, in the register of Maisie's consciousness, of 'the splendour of the afternoon sea, and the haze of the far headlands, and the taste of the sweet air'.[39] Maisie seems to be discovering the mystery of her own property of mind, just as James will do at the end of the first volume of his autobiography.

James writes that Maisie 'was abandoned to her fate' following her parents' divorce.[40] It is the author who abandons her for the second time at the end of the novel. He replied with characteristic evasiveness to Mrs. John Chandler Bancroft, who asked him to divulge what happened next, in a letter of 21 March 1898, that 'what the end - where the end, in that sort of thing, ever is, I feel that I can never say'.[41] Maisie is left on the brink of adolescence. She is identity and potential embodied.

\section{Lolita: Thwarted Potential}

While Maisie reaches the cusp of the adolescent transition at the end of James's novel of development, Dolores Haze's development is thwarted in Lolita by Humbert's cruel appropriation of her childhood. In her comparative survey of representations of the child in contemporary culture, Ellen Pifer argues against the widely held view that in Lolita Nabokov challenged the myth of childhood innocence. Pifer proposes that Lolita in fact reflects Nabokov's indebtedness to a Wordsworthian notion of the child. She suggests that, 'like James's Maisie, Nabokov's children are vigorous creatures in whom the seeds of adult energy and sexuality, will and intelligence are firmly rooted'.[42] Pifer's description could apply equally well to Nabokov's adolescent self-portrait. 
Lolita's vocational potential is demonstrated when Humbert recalls her tennisplaying. He describes the 'exquisite clarity of all her movements', 'the pure ringing sound of her every stroke', and the 'beauty, directness, youth [and] classical purity of trajectory' of her service, overawed by the power and erotic energy of her game.[43] Yet Humbert's observations are marred by his perception that something in her is missing, and 'broken' by him; otherwise, she 'would have had on top of her perfect form the will to win, and would have become a real girl champion'.[44] Richard Rorty has argued compellingly that, in his cruelty towards Lolita and incuriosity about her, Humbert is a partial self-portrait of the author.[45] Rorty suggests that Humbert's characterization reflects Nabokov's guilt about the effects of his obsession with his writing on others.[46]

Humbert also prevents Lolita from realising her sexual or romantic potential. Lolita was in love with Clare Quilty, not with Humbert. Even though Quilty is a no less unsavoury character than Humbert, Lolita's love for him is an expression of her own will, self-direction, and interests. Erikson suggests that during the adolescent period of testing out one's identity, "'falling in love"' is '[not] entirely, or even primarily, a sexual matter', arguing that 'to a considerable extent adolescent love is an attempt to arrive at a definition of one's identity by projecting one's diffused self-image on another'.[47] Lolita loves 'Cue', perhaps, because he is a famous actor; she wants to be an actor herself. While Maisie is emblematic of open-ended potential, Lolita's development is thwarted along both the sexual and social trajectories I identified in Nabokov's self-portrayal in Speak, Memory. Nabokov's depiction of Lolita's adolescent vitality and potential renders Humbert's cruelty, and her untimely death in childbirth, 'hopelessly worn at seventeen', all the more crushing.[48]

\section{Antoinette in Wide Sargasso Sea: Reclamation of Potential}

As Sandra Gilbert and Susan Gubar have argued, there is a stark contrast between the self-determined, positive destiny provided for Jane Eyre in Charlotte Brontë's novel, and the darker consciousness and fate experienced by Jean Rhys's Antoinette/Bertha in Wide Sargasso Sea.[49] Antoinette is a white Creole from a former slave-owning family, as was Rhys herself. Antoinette grows up in the West Indies just after the emancipation of the slaves in Dominica in the 1830s. The black people on the island call her 'a white cockroach', while white English women call the family 'white niggers'. Antoinette says to Rochester after they are married, when she is not yet twenty years old, 'Between you all I often wonder who I am'.[50] As we have seen, Erikson suggests that the resolution of the crisis of identity involves the 'anticipated recognition of those who count'.[51] Yet Antoinette experiences the opposite of this.

It is possible to read the childhood and adolescence of Antoinette, like those of Lolita, as leading ineluctably to the death of her potential and the stifling of her sense of identity. She is predestined to become Bertha Mason, the adult woman described by Brontë's Mr Rochester: 'Bertha Mason is mad; and she came of a mad family; 
idiots and maniacs through three generations!'[52] Then she dies - a lunatic who sets fire to her husband's house, and jumps from the roof. Yet Rhys's novel provides for 'Bertha Mason' the explanatory political and social pre-history, the 'particularity', she lacks in Brontë's work, as David Todd and Kenneth Womack have suggested.[53] I would argue further that Rhys also engenders in her character a sense of identity and direction.

In the diary entry in which Rhys re-constitutes her own self-as-writer, she states: 'I have been accused of madness. But if everything is in me, good, evil and so on, so must strength be in me'.[54] Through the performative medium of diary-writing at this critical moment in her career Rhys inwardly negates the accusation of madness, and returns to strength. When Antoinette/Bertha dreams in the final pages of Wide Sargasso Sea of burning down Thornfield Hall, she narrates that this 'reminded me of something I must do'.[55] Her dream gives her a sense of direction, a sense, to return to Erikson's original definition, of 'where she is going'. Just a few pages earlier, Antoinette says to Grace Poole, that 'If you are buried under a flamboyant tree [...] your soul is lifted up when it flowers', a recollection from her childhood in the West Indies.[56] Rhys recasts Antoinette/Bertha's suicide as a defiant reclamation of identity. Antoinette performs a symbolic act of self-restitution and commemoration, lighting up the pages of the future with red flames.

\section{The Novels of Adolescence within their Authors' Careers}

I shall now explore how these novels of adolescence are located within their authors' careers and suggest that in each case the principal character's adolescent transition can be seen as a metaphor for development and transition in the author's own writing life. What Maisie Knew accompanied a progressive step in which James began to move into his third phase as an author. The writing of Lolita accompanied Nabokov's taking up of an Americanized authorial identity, and its controversial success guaranteed him lasting recognition. The acclaim for Wide Sargasso Sea led to the re-issue of Rhys's earlier novels and the establishment of her international reputation as a writer.

\section{What Maisie Knew and Henry James's writing career: Into the Third Phase}

What Maisie Knew (1897) belongs to the middle period of James's career. Edel places the novel second in what he sees as a series of books by James about children, principally girls, that describes an arc of development from early childhood to adolescence: The Other House (1896), The Turn of the Screw (1898), In the Cage (1898), and The Awkward Age (1899).[57] Edel interprets this group of books in biographical terms, as a therapeutic writing-out of James's lack of success as a playwright, and in particular the humiliation and defeat he suffered on the opening night of his play Guy Domville in 1895.[58] For Edel, James was writing himself back into the experiences of his childhood through Maisie and this group of novels, and this was therapeutic for him. Edel thus draws on Freud for his 
suggestion that What Maisie Knew was part of a regression into childhood for James.

I propose a positive, progressive formulation of this process, drawing on Erikson's ideas about the adolescent identity crisis.[59] Through Maisie James fictionalized the identity-formative moments of his adolescence. I wish to suggest that this reflects James's engagement in a gradual process of re-defining his own adult identity in a positive way following the failure of social recognition of his identity as playwright. James was experiencing a recurrence of the Eriksonian identity crisis.

Most critics agree that What Maisie Knew was a pivotal work for James, breaking new ground in its combination of highly formal structure, its dramatic intensity, and, arguably, in terms of the mode of its composition, since it was whilst composing this book that James was forced by writer's cramp to begin dictating to a secretary, as Paul Theroux notes in his introduction.[60] More than the adolescent Nanda and Aggie in The Awkward Age, or Daisy in Daisy Miller (1878), the child Maisie stands out in being so autobiographical a creation.[61] What Maisie Knew is also distinguished from these two other stories of adolescence in its controlled style. The almost flawless use of Maisie as 'ironic centre' to foreground the activity of the adults around her connects the novel to James's subsequent experimental works exploring psychological ambiguity, The Turn of the Screw and The Sacred Fount (1900), neither of which exhibit as a bright, inquisitive, and memorable character as Maisie.

It is also possible that What Maisie Knew was a transitional work for James in terms of his treatment of sexuality.[62] Maisie is a 'wonder-working agent' for James as an author: through her, critically, and at several different levels, he works through to a new phase of his style, and to the technical mastery exemplified in his late novels, and the autobiography. Just as adolescence is a liminal stage between childhood and adult worlds, so What Maisie Knew forms a bridge to James's later works. In writing it, James makes a breakthrough into a period of renewed potential - he 'readolescences', forging a revised writing identity.

\section{Lolita and Vladimir Nabokov's Writing Career: 'Lo' as American Love-Object}

In his autobiography Nabokov uses the distancing third person to describe Sirin, a writer. 'Sirin' is in fact the pseudonym Nabokov himself used as a Russian author; he is, we are told, 'the author that interested me most naturally'. [63] As Michael Wood argues, the grammar of the third person which Nabokov uses is not just a playful postmodern rendering of multiplicity of self. It also enables Nabokov to distance this character from his primary narrating identity. Sirin was, according to Wood, 'another writer [...] an old self but also a different artist [...] not yet the writer [Nabokov] was to be'.[64] Lolita was a transitional novel for Nabokov because it turned him into a world-famous author, and enabled him, like James, to progress beyond a past self. 
First published in Paris in 1955, Lolita was not the first novel Nabokov wrote in English. This was The Real Life of Sebastian Knight (1941), in which the narrator in his polite, supposedly self-effacing and gently pompous self-characterization, is more English than the English.[65] Lolita was however the first and ultimately most popular, if the most controversial, of the group of novels in English which made Nabokov's reputation, which include Pale Fire (1962) and Ada (1968).

Brian Boyd's parallel reading of Lolita and Speak, Memory suggests that Lolita is a culmination of Nabokov's actual, 'real-life' experiences of love, themselves blurring seamlessly into fiction.[66] Boyd's biographical reading arguably falls into the tradition of viewing Lolita as a version of a courtly love narrative. The main difference, however, is that it is an American version. In writing the character Lolita, whose adolescent potential Humbert appropriates, Nabokov creates for himself a fresh, fictionalized love-object, a projected American self. If Humbert is a direct autobiographical identification, as Richard Rorty and others have argued, Lolita is a projective identification, as Quilty was for her. Rachel Bowlby provides an interesting reading of Lolita as a novel which continues a European tradition, via Nabokov's debt to Poe, Proust, and other European writers, at the same time as incorporating into its prose-poetry the 'mass-cultural' elements of Lolita's country, and her 'low culture' teenage interests. [67] The character Lolita reflects Nabokov's own aspiration towards, and ultimately his transformation into, an American-adapted self. What Bowlby describes as Nabokov's immersion in the language and iconography of American culture is also his re-definition after exile from his Russian past.

\section{Wide Sargasso Sea and Jean Rhys's Career: Not Just Autobiographical Fiction}

Wide Sargasso Sea established Rhys as an internationally recognised author on its publication in 1966. Its success resulted in the re-issue of her four earlier novels published before the war, including Voyage in the Dark (1934) and Quartet(1928, as Postures) which had been out of print. Carole Angier has referred to the period when Rhys's work was not available as her lost years.[68]

Sylvie Maurel argues compellingly that through the writing of Wide Sargasso Sea Rhys formed a conscious relation to an earlier woman writer, Charlotte Brontë, thereby extending and contributing to a tradition of women writers, [69] an example of the feminine version of Bloom's 'anxiety of influence' described by Gilbert and Gubar.[70] The inter-textual relationship with Jane Eyre also distinguishes this novel from Rhys's more directly autobiographical earlier novels written before the war (Quartet for example, is a very thinly veiled re-casting of her relationship with the writer Ford Madox Ford).

Voyage in the Dark is, like Wide Sargasso Sea, a novel of adolescence, though, developed from the notebooks referred to earlier, it is arguably the more highly autobiographical work. Thorunn Lonsdale describes, nonetheless, how the character 
Anna in Voyage is related to Zola's eponymous Nana.[71] Nana is a French prostitute who dies of smallpox at the end of Zola's novel, so, as Lonsdale argues, Rhys is foreshadowing Anna's own death when she has Anna read the novel Nana. In the original manuscript version of Voyage, Anna dies at the end of the novel, after she undergoes an illegal termination of pregnancy.[72] The published version of the ending is ambiguous. In attempting to kill off an autobiographically identified character, Rhys may have been marking a developmental transition in her own life.

Although Antoinette's characterization in Wide Sargasso Sea is highly autobiographical, Carole Angier argues that Antoinette differs from Rhys because Antoinette's suicide is a destructive act, whereas Rhys's writing of the novel is creative.[73] I have argued however that Antoinette's suicide is transformed under Rhys's description in the novel into an aesthetic, performative act of self-restitution. Lonsdale's observations about Rhys's intended ending for Voyage lend further weight to the possibility that Antoinette's death in fact liberates, or transforms, Rhys in the same way that the fates of Nabokov's and James's adolescent characters correspond to transitions in their adult lives. The autobiographical significance of Wide Sargasso Sea within Rhys's career lies, paradoxically, in its relation to Jane Eyre. Rhys identifies with Antoinette, but since Antoinette is Brontë's character, she cannot be wholly autobiographical. Antoinette's self-determined, defiant suicide thus becomes a powerful, transformative metaphor - and in practical terms a vehicle - for Rhys's late step into lasting recognition.

\section{Conclusion}

Erikson became intrigued late in his own career with the question of how some adults continue to re-invent themselves in later life.[74] In his earlier writing he had said that 'identity formation neither begins nor ends with adolescence'. [75] All three of the writers in this study re-constituted their identities during adulthood, and moved forwards into renewed and re-potentiated phases in their work. Erikson's own early research into adolescence suggests a solution to the conundrum of continued development in adulthood he raised in later life: perhaps potential in adulthood is kept alive through the recurrence of adolescence and the concomitant crisis of identity. James, Nabokov, and Rhys combined the creative writing of novels with transformations in their own adult careers. During their adult lives they each achieved a transition into a revised authorial identity. They 'came of age' as writers. A dynamic, developmental process animates both the characters in their fiction, and their writing lives.

Amy Lankester-Owen obtained her B.A. in Philosophy and Physiological Sciences from Oxford and her M.A. in Literature and Writing Lives at King's College London. As Editorial Director at Jessica Kingsley Publishers she commissioned titles in child and adolescent psychiatry and psychology, and family and childcare policy. This article is an adapted and abridged version of an unpublished M.A. dissertation called 'Writing Adolescence: Identity and Transformation in the Autobiographies of Henry 
James, Vladimir Nabokov, and Jean Rhys and their Career-Pivotal Developmental Novels What Maisie Knew, Lolita, and Wide Sargasso Sea'.

\section{Bibliography}

\section{Primary Texts}

Brontë, Charlotte, Jane Eyre (1847), ed. by Q. D. Leavis (London: Penguin, 1966; repr. 1985)

James, Henry, Henry James: Autobiography, ed. by F. W. Dupee (London: W. H. Allen, 1956)

—. Henry James: A Life in Letters, ed. by Philip Horne (London: Allen Lane, 1999)

—. What Maisie Knew, ed. by Paul Theroux (London: Penguin, 1985)

Nabokov, Vladimir, Lolita, afterword by Craig Raine (London: Penguin, 2000)

—. Speak, Memory, ed. by Brian Boyd (London and New York: Knopf, 1999)

Rhys, Jean, Smile Please: An Unfinished Autobiography, foreword by Diana Athill (London: André Deutsch, 1979)

—. Wide Sargasso Sea (1966), ed. by Angela Smith (London: Penguin, 2000)

\section{Secondary Texts}

Angier, Carole, Jean Rhys: Life and Work (London: Penguin, 1992)

Bowlby, Rachel, Shopping with Freud (London and New York: Routledge, 1993)

Bradley, John R., ed., Henry James and Homoerotic Desire (Basingstoke: Palgrave Macmillan, 1999)

Edel, Leon, Henry James: A Life (London: Collins, 1987)

Erikson, Erik H., Childhood and Society (London and New York: W. W. Norton, 1963)

-. Identity and the Life Cycle (London and New York: W. W. Norton, 1980)

-. Identity: Youth and Crisis (London and New York: W. W. Norton, 1968) 
Freud, Anna, Normality and Pathology in Childhood: Assessments of Development (London: Karnac Books and the Institute of Psychoanalysis, 1989)

Gilbert, Sandra, and Susan Gubar, The Madwoman in the Attic: The Woman Writer and the Nineteenth Century Literary Imagination (New Haven and London: Yale University Press, 1979)

Hren Hoare, Carol, 'Erikson and Rethinking the Meaning of "Adult"', in Erikson on Development in Adulthood: New Insights from the Unpublished Papers (Oxford: Oxford University Press, 2002)

Lonsdale, Thorunn, 'Literary Allusion in the Fiction of Jean Rhys', in Caribbean Women Writers: Fiction in English, ed. by Marie Condé and Thorunn Lonsdale (Basingstoke: Macmillan, 1999)

Marcus, Laura, Auto/biographical Discourses: Criticism, Theory, Practice (Manchester: Manchester University Press, 1994)

Maurel, Sylvie, Women Writers: Jean Rhys (Basingstoke: Macmillan, 1998)

Pifer, Ellen, Demon or Doll: Images of the Child in Contemporary Writing and Culture, (Charlottesville and London: University Press of Virginia, 2000)

Rorty, Richard, Contingency, Irony and Solidarity (Cambridge: Cambridge University Press, 1989)

Stevens, Hugh, Henry James and Sexuality (Cambridge: Cambridge University Press, 1998)

Todd, David, F., and Kenneth Womack, 'Reclaiming the Particular: The Ethics of Self and Sexuality in Wide Sargasso Sea', Jean Rhys Review, 11 (1999), 103-118

Wood, Michael, The Magician's Doubts: Nabokov and the Risks of Fiction (Princeton, NJ: Princeton University Press, 1994)

[1] Laura Marcus, Auto/biographical Discourses: Criticism, Theory, Practice (Manchester: Manchester University Press, 1994).

[2] See, for example, Anna Freud, Normality and Pathology in Childhood: Assessments of Development (London: Karnac Books and the Institute of Psychoanalysis, 1989), pp. 163-64. Anna Freud distinguishes 'pre-adolescence' from the preceding latency phase, suggesting that even this phase is characterized by 'a severe loss of social adaptation' relative to latency (p. 163). She states that 'in 
the more severe cases' the adolescent phase proper is of a 'quasi-dissocial, quasipsychotic, borderline order' (p. 164).

[3] Eric H. Erikson, Identity: Youth and Crisis (London and New York: W. W. Norton, 1968), p. 156.

[4] Part I of Eric H. Erikson's Childhood and Society (London and New York: W. W. Norton, 1963) explores in detail the inter-relationship between Freud's staged model of development and Erikson's own. Carol Hren Hoare provides a useful summary of Erikson's criticisms of and extensions of Freud's work in 'Erikson and Re-Thinking the Meaning of "Adult"', in Erikson on Development in Adulthood: New Insights from the Unpublished Papers (Oxford: Oxford University Press, 2002), pp. 24-35.

[5] Erikson, Identity: Youth and Crisis, pp. 135-41.

[6] The Latin suffix '-scere' connotes a change of state, a becoming. Thus 'adolescence' is the process of becoming, or growing into, an adult.

[7] Erikson, Identity: Youth and Crisis, p. 156.

[8] Erikson, Identity: Youth and Crisis, p. 165.

[9] Henry James, Henry James: Autobiography, ed. by F. W. Dupee (London: W. H. Allen, 1956), pp. vii-ix and xi-xii. According to Dupee, James's original idea for a shorter book - a memoir of his brother William James, together with a selection of William's letters - evolved into 'an extended account of his own early development' (p. vii); a subsequent volume, Notes of a Son and Brother (1914), contains more material commemorating the James family. A third volume, The Middle Years(1917), was left unfinished at James's death in 1916.

[10] James, Henry James: Autobiography, p. viii.

[11] James, Henry James: Autobiography, p. 159.

[12] James, Henry James: Autobiography, p. 158.

[13] Erikson, Identity: Youth and Crisis, p. 20. Erikson is referring to a letter of William James's (from which he quotes) for a case example of what a sense of continuous identity feels like (pp. 19-20). This suggests the possibility of extending my research into an inquiry into the influence of the psychologist William James on Erikson's ideas. One might then consider whether connections exist between the James family's philosophy and that of Erikson on identity and potential.

[14] Hugh Stevens, Henry James and Sexuality (Cambridge: Cambridge University Press, 1998), pp. 133-34. 
[15] Marcus, p. 2.

[16] According to Brian Boyd in his introduction to Speak, Memory, Nabokov wrote most of the original text of the autobiography in the 1940s in the form of a series of pieces for The New Yorker and did so partly for financial reasons. A Russian translation was published in 1954 as Drugie Berega ('From the Other Shore'). The first English language edition of the autobiography was therefore published before the controversial success of Lolita, eventually published in America in 1958. (Nabokov, Speak, Memory, p. xxiii-xxv).

[17] Vladimir Nabokov, Speak, Memory, ed. by Brian Boyd (London and New York: Knopf, 1999), p. 16 and 106.

[18] Nabokov, Speak Memory, p. 168.

[19] Nabokov, Speak, Memory, p. 161.

[20] Nabokov seems to have felt a certain antagonism towards Freud. In Speak Memory he alludes with characteristic mischievousness to 'Sigismond Lejoyeux, a local aeronaut' engaged in inflating 'a huge custard-colored balloon' (p. 120).

[21] Erikson, Identity: Youth and Crisis, p. 156.

[22] The autobiography is a slightly problematic text for research. Rhys died before it was completed, and was thus unable to apply her characteristic perfectionism in scrutinizing the final version prior to publication (as described by Athill in Rhys, Smile Please, p. 8). The work was also unusual in being a collaboration with another writer. Further research on this subject would need to take in the wider autobiographical material available in the form of letters and journals.

[23] Jean Rhys, Smile Please: An Unfinished Autobiography, foreword by Diana Athill (London: André Deutsch, 1979).

[24] Rhys, Smile Please, p. 130. Some years later the notebooks would be reworked into the novel Voyage in the Dark (1934).

[25] Foreword to Smile Please, pp. 5-6.

[26] The diary excerpts appear in Rhys, Smile Please, pp. 159-173 and are collectively entitled 'From a Diary: At the Ropemaker's Arms'. Diana Athill describes in her foreword how Rhys intended to include some of this material, but died before she was able to finish editing and selecting from it. It was Athill who performed the selection and editing in her place (p. 8).

[27] Rhys, Smile Please, p. 8. 
[28] Rhys, Smile Please, p. 168, in section entitled 'About England and the English'.

[29] Rhys, Smile Please, p. 163, in section entitled 'Trial Continued', a continuation of 'The Trial of Jean Rhys' which opened on p. 159.

[30] Laura Marcus argues that 'auto/biographical' literature has evolved to include different forms in a way that parallels the evolution of literary studies (Marcus, p. 7 and 281). That this extract from Rhys's diary is the most powerful voicing of her writing identity in her literary autobiography implies that she is questioning the borders between the private and public spheres in the same way that Nabokov interrogates the generic distinction between fiction and life writing.

[31] Erikson, Identity and the Life Cycle (London and New York: W. W. Norton, 1980), p. 122.

[32] Rhys, Smile Please, p. 168.

[33] Henry James, What Maisie Knew, ed. by Paul Theroux (London: Penguin, 1985), p. 13.

[34] James, What Maisie Knew, p. 29.

[35] James, What Maisie Knew, p. 31.

[36] Leon Edel, Henry James: A Life (London: Collins, 1987), pp. 480. Edel writes that 'Maisie is a careful presentation of the Henry James of the late autobiography $A$ Small Boy and Others: she possesses his curiosity [...] she searches determinedly for her identity'.

[37] Edel, pp. 480-81.

[38] James, What Maisie Knew, p. 9.

[39] James, What Maisie Knew, p. 211.

[40] James, What Maisie Knew, p. 36.

[41] Henry James, Henry James: A Life in Letters, ed. by Philip Horne (London: Allen Lane, 1999), p. 299.

[42] Ellen Pifer, Demon or Doll: Images of the Child in Contemporary Writing and Culture (Charlottesville and London: University Press of Virginia, 2000), quotation from p. 76.

[43] Vladimir Nabokov, Lolita, afterword by Craig Raine (London: Penguin, 2000), p. 231 and 232. 
[44] Nabokov, Lolita, p. 232.

[45] Richard Rorty, Contingency, Irony and Solidarity (Cambridge: Cambridge University Press, 1989), pp. 157-164.

[46] Rorty, pp. 158-61.

[47] Erikson, Identity: Youth and Crisis, p. 132.

[48] Nabokov, Lolita, p. 277.

[49] Sandra Gilbert and Susan Gubar, 'A Dialogue of Self and Soul: Plain Jane's Progress', in The Madwoman in the Attic: The Woman Writer and the Nineteenth Century Literary Imagination (New Haven: Yale University Press, 1979), pp. 336-71. On pp. 359-60 the authors suggest that Bertha is Jane's 'avatar' and 'dark double'.

[50] Jean Rhys, Wide Sargasso Sea, ed. by Angela Smith (London: Penguin, 2000), p. 64.

[51] Erikson, Identity: Youth and Crisis, p. 165.

[52] Charlotte Brontë, Jane Eyre, ed. by Q.D. Leavis (London: Penguin, 1966; repr. 1985), p. 320.

[53] David F. Todd and Kenneth Womack, 'Reclaiming the Particular: The Ethics of Self and Sexuality in Wide Sargasso Sea', Jean Rhys Review, 11 (1999), pp. 10318.

[54] Rhys, Smile, Please, p. 164.

[55] Rhys, Wide Sargasso Sea, pp. 121-22.

[56] Rhys, Wide Sargasso Sea, p. 120.

[57] Edel, pp. 480-83. This section of Edel's biography is entitled 'The Little Girls'.

[58] See Edel, p. 420 and 481. On p. 481 Edel writes that 'in resuming, after the trauma of Guy Domville, the disguise of a female child, the protective disguise of his early years, James performed unconscious self-therapy'. His argument is thus a Freudian one: he goes on to suggest that James regressed to the imaginative and emotional world of his childhood as a defensive mechanism.

[59] Hren Hoare suggests that Erikson specifically moved away from Freud in his concentration on the possibility of development in adulthood. Erikson considered that Freud had a negative view of adulthood and that he relied too heavily on the notion of the supposed formativity of childhood experience (pp. 24-25). 
[60] James, What Maisie Knew, Introduction, pp. 10-11.

[61] Edel connects What Maisie Knew in particular with A Small Boy and Others (1913), in terms of its autobiographical presentation of a child's consciousness (pp. 480-81).

[62] John R. Bradley, in his chapter entitled 'Henry James's Permanent Adolescence' in Henry James and Homoerotic Desire, ed. by John R. Bradley (Basingstoke: Palgrave Macmillan, 1999), pp. 45-69 suggests that following the Wilde Trial in 1895 and during the 1880s and 1890s when psychological theory about homosexuality burgeoned, James began to codify the homosexual in his novels more consciously (p. 60-62), writing 'tales which, while not explicitly or exclusively homosexual, would be recognised as dealing with the theme by the initiated' (p. 63). Perhaps Maisie's gender - which, as we have seen, is omitted from consideration in Edel's analysis, despite his contention that she is a directly autobiographical portrait of James - lends support to this notion. Sir Claude begins to call Maisie 'old boy' as she grows into adolescence, seemingly unsexing her. Perhaps, to a homosexual readership, he was doing the opposite.

[63] Nabokov, Speak, Memory, p. 225.

[64] Michael Wood, 'The World Without Us: Speak, Memory', in The Magician's Doubts: Nabokov and the Risks of Fiction (Princeton, NJ: Princeton University Press, 1994), pp. 83-103; discussion of Sirin on pp. 100-01; quotation from p. 101.

[65] Nabokov was welcomed by the academic establishment in the United States but not in Britain, where his anti-Communism did not make him popular, and where he recounts 'hopelessly trying to find an academic job' (Speak, Memory, p. 212). The English self-identification of the narrator in The Real Life of Sebastian Knight is not one that succeeds in being transformative, in taking seed.

[66] Nabokov, Speak, Memory, Introduction, pp. ix-xii.

[67] Rachel Bowlby, Shopping with Freud (London and New York: Routledge, 1993), pp. 60-67.

[68] Carol Angier, Jean Rhys: Life and Work (London: Penguin, 1992). 'The Lost Years' is the title of Part Three, on pp. 411-525.

[69] Sylvie Maurel, Women Writers: Jean Rhys (Basingstoke: Macmillan, 1998), pp. 135-142.

[70] Gilbert and Gubar, 'Infection in the Sentence: The Woman Writer and the Anxiety of Authorship', in The Madwoman in the Attic, pp. 45-92. 
[71] Thorunn Lonsdale, 'Literary Allusion in the Fiction of Jean Rhys', in Caribbean Women Writers: Fiction in English, ed. by Marie Condé and Thorunn Lonsdale (Basingstoke: Macmillan, 1999), pp. 53-54.

[72] See note 5.13 in the catalogue of Voyage in the Dark manuscripts held at the University of Tulsa

Special

Collection, http://www.lib.utulsa.edu/Speccoll/rhysjol.htm.

[73] Angier, p. 567.

[74] Hren Hoare, p. 27.

[75] Erikson, Identity and the Life Cycle, p. 122. 